\title{
INSOL Europe's proposals on groups of companies (in cross-border insolvency): a critical appraisal
}

\author{
Dr Irit Mevorach*
}

\section{$\underline{\text { Introduction }}$}

The regulation of corporate groups is a challenging task. Groups come about in different permutations and they often present a tension between the economic reality whereby they operate as a single entity and the legal position which allows them to be split into separate legal persons. ${ }^{1}$ In the context of cross-border insolvency, groups' structures present two key regulatory challenges. One is how to facilitate an efficient procedural coordination of the insolvency proceedings (including group-wide restructurings) where the group is spread across different countries; and the other is, how to deal (in the course of insolvency) with scenarios of heavily integrated groups whose assets or debts have been intermingled.

Although group structures are likely the most common structure for large cross-border enterprises, it took international bodies quite some time before they have started addressing the matter. UNCITRAL Working Group V (which deals with insolvency law reform) took on board to address both the domestic and international aspects pertaining to groups in 2006, a project that was finalised in 2010 and resulted in a set of recommendations added to the UNCITRAL Legislative Guide on Insolvency Law. ${ }^{2}$ Yet, the UNCITRAL Model Law on Cross-Border Insolvency (the Model Law) ${ }^{3}$ is still confined to single companies. The EC

\footnotetext{
${ }^{*}$ Associate Professor, University of Nottingham. The Article is based on a presentation delivered at the INSOL Europe/ Ernst-Jaeger-Institute joint international insolvency seminar, Revision of the European Insolvency Regulation Leipzig University, Germany, 14 September 2012.

${ }^{1}$ See generally I Mevorach, Insolvency within Multinational Enterprise Groups (OUP, 2009).

${ }^{2}$ U.N. Comm'n on Int'I Trade Law [UNCITRAL] Legislative Guide on Insolvency Law 2004, Part III.

${ }^{3}$ U.N. Comm'n on Int'I Trade Law (UNCITRAL), UNCITRAL Model Law on Cross-Border Insolvency with Guide to Enactment, U.N. Sales No. E.99.V.3.
} 
Regulation on Insolvency Proceedings (the EC Insolvency Regulation) ${ }^{4}$ does not deal with corporate groups either. The Regulation is now undergoing revision, though, and it is expected that some consideration of the group scenario will be taken on board, even if the issue may not be fully addressed at this stage. ${ }^{5}$ UNCITRAL Working Group V is now also deliberating on the refinement of the Guide to Enactment of the Model Law, specifically in relation to the notion of COMI and associated issues, which may have implications to groups. ${ }^{6}$ Here too, though, it is expected that the cross-border insolvency of groups will not be fully addressed at this stage. Evidently, the regulation of groups is a complex task and therefore may require an incremental process, whilst the debate regarding regulating groups in insolvency is ongoing.

In light of these recent developments and the expectation that more will come in terms of international development, it is timely and important to assess the proposals of INSOL Europe regarding groups. INSOL Europe ("INSOL") (the European organisation of professionals who specialise in insolvency, bankruptcy and business reconstruction and recovery) has a leading role in European insolvency and restructurings. In anticipation of the revision of the EC Insolvency Regulation (required under article 46 of the Regulation) INSOL composed a thorough report with proposed amendments to the Regulation including an in depth consideration of the group problem. Its recommendations may, therefore, have an impact within Europe (either at this stage of the revision or later on) and beyond. It is also the case that any new rules regarding groups that may be enacted by regional or international bodies will follow a process of implementation in domestic regimes or application by

\footnotetext{
${ }^{4}$ Council Regulation 1346/2000.

${ }^{5}$ In light of the short timetable for finalising the revision it is expected that some issues (including further consideration of harmonisation of insolvency laws) will be postponed to a second regulatory stage.

${ }^{6}$ See latest report: A/CN.9/742 Report of Working Group V (Insolvency Law) on the work of its forty-first session, New York, 30 April-4 May 2012.
} 
national courts which will require understanding of the purpose and policy considerations underlying the rules. Certain legal regimes are already undergoing consideration of reform of their group insolvency laws. Others may follow suit. These initiatives could also benefit from the work of organisations such as INSOL, specifically INSOL's proposals regarding groups. This is especially so as the proposals seem to go somewhat beyond mere cross-border procedural aspects, and address, for example, the circumstances where substantive consolidation should apply. Generally, the proposals could contribute to the general debate regarding the regulation of groups in insolvency. ${ }^{7}$

\section{What is in the INSOL's proposals?}

INSOL's report deals with the group problem quite comprehensively. One chapter is devoted to groups and proposes the concepts of coordination via a group main proceeding and of substantive consolidation (Chapter V). Another chapter suggests the concept of EU rescue plans specifically targeted at corporate groups (Chapter VI). Further references to groups are evident in the proposed amendments to the definitions in the Regulation (Chapter I) including that of COMI, which is the focal point of the Regulation.

Understandably, the proposals do not deal with certain other matters pertaining to groups in insolvency such as whether or not to avoid intra-group transactions ${ }^{8}$ or whether to make a parent company liable for the debts of its subsidiaries. ${ }^{9}$ These matters are certainly outside the purview of the Regulation which is essentially a private international law instrument aimed at unifying matters of jurisdiction, recognition, enforcement and choice of law. It is

\footnotetext{
${ }^{7}$ On which see e.g. I Mevorach, Insolvency within Multinational Enterprise Groups (OUP, 2009); B. Wessels, "Multinational Groups of Companies under the EC Insolvency Regulation: where do we stand?", Ondernemingsrecht 2009-5, 243; N.W. Tollenaar, "Dealing with the Insolvency of Multinational Groups under the European Insolvency Regulation" Tijdschrift voor Insolventierecht 2010, 94.

${ }^{8}$ See I Mevorach, 'Bankruptcy of Corporate Groups and Transaction Avoidance' (2011) 2 ECFR 235.

${ }^{9}$ See I Mevorach, Insolvency within Multinational Enterprise Groups (OUP, 2009), Ch 9.
} 
even questionable whether it is within the ambit of the Regulation to impose harmonised rescue plans and rules regarding substantive consolidation as proposed in the report. Yet, what is interesting to consider is not so much the legal instrument for implementing the rules but rather the concepts themselves, their rationale and desirability.

\section{Structure, aim and methodology of the paper}

The paper focuses on the proposals of INSOL in Chapter V of its report, namely the concepts of coordination via a group main proceedings, and substantive consolidation. Consideration of the proposals in other chapters which are also relevant to groups (and to which Chapter $\mathrm{V}$ itself refers) will be made throughout the analysis where relevant, though the details of the proposed EU rescue plan (in Chapter VI of the report) are outside the scope of this paper. In the rest of the paper, the proposals regarding coordination and substantive consolidation will be first described. It will then be assessed to what extent they can meet the challenge of facilitating the resolution of groups' cross-border insolvency proceedings. This evaluation will take account of both the variety of possible group structures and the goals the insolvency regime would aim to achieve. ${ }^{10}$ In the process, the merits of the proposals will be revealed but also their shortcomings.

\section{An overview of INSOL's proposals regarding corporate groups}

Appreciating the need to ensure a close and efficient coordination of group proceedings, which may take place in multiple jurisdictions, INSOL suggests that such proceedings will be

\footnotetext{
${ }^{10}$ See further I Mevorach, Insolvency within Multinational Enterprise Groups (OUP, 2009), Ch 4 and 5.
} 
closely coordinated. It is proposed to achieve this by opening what is termed in the proposal a "group main proceedings" at the jurisdiction of the "ultimate parent company". 11

An ultimate parent company is defined as a parent company which has its centre of main interests ("COMI") in the EU and which is subject to insolvency proceedings under the Regulation (and which itself does not have a parent company which has its COMI in the EU). ${ }^{12}$ Subsidiaries are defined as companies which are owned or controlled by the parent company. ${ }^{13}$ The definition of a parent company is taken from the $7^{\text {th }}$ EC Directive on group accounts with some modifications. ${ }^{14}$ It is based on the holding of the majority of the shareholders' or members' voting rights in the other company (i.e. the subsidiary), or (if no company meets such definition), having the right to appoint or remove a majority of the members of the administrative, management or supervisory body of the other company and being at the same time a shareholder in or member of that other company, or (if no company meets the above definitions), the company that has the right to exercise a dominant influence over another company of which it is a shareholder or member, pursuant to a contract entered into with that other company or to a provision in its memorandum or Articles of association. ${ }^{15}$

The idea is then that the proceedings of the group of companies (defined as a number of companies consisting of parent and subsidiary companies) ${ }^{16}$ will be coordinated via the control of the ultimate parent's proceedings, taking place at its COMI. COMI under the Regulation is the centre of the main interest of the company which is presumed to be at the company's registered office. ${ }^{17}$ Otherwise, COMI is not currently defined in the Regulation. INSOL suggests to clarify that COMI means (in the case of companies and legal persons) the

\footnotetext{
${ }^{11}$ Proposed article 43.

${ }^{12}$ Proposed article 2(n).

${ }^{13}$ Proposed article 2(m).

${ }^{14}$ Seventh Council Directive 83/349/EEC of 13 June 1983 based on the Article 54 (3) (g) of the Treaty on consolidated accounts.

${ }^{15}$ Proposed article 2(I).

${ }^{16}$ Proposed article 2(j).

${ }^{17}$ Article 3(1) of the EC Insolvency Regulation.
} 
place of the registered office, except that where the operational head office functions are carried out in another Member State and that other Member State is ascertainable to actual and prospective creditors as the place where such operational head office functions are carried out, it shall mean and refer to the Member State where such operational head functions are carried out. Furthermore, where the company is a mere holding company, within a group with head office functions in another Member State, the centre of main interests (as defined above) is located in such other Member State. It is further suggested that the mere fact that the economic choices and decisions of a company are or can be controlled by a parent company in another Member State does not cause the centre of main interests to be located in this other Member State. ${ }^{18}$

Additional main proceedings will be opened against the relevant subsidiaries in their respective COMIs (based on the same definition, as explained above). The liquidators in the group main proceedings and subsidiaries' main proceedings will be then duty bound to cooperate with each other. ${ }^{19}$ Furthermore, the group main liquidator will have powers to intervene in the subsidiaries' proceedings, by analogy to the relationship between "main" proceeding (opened at the company's COMI) and the "secondary" proceeding (opened where the company has an establishment) which has a subordinate nature under the Regulation. ${ }^{20}$ Importantly, the group main liquidator will be able to ask to stay the subsidiary's proceedings. ${ }^{21}$ He may also propose a rescue plan, either based on procedures available in the subsidiary's forum or based on the proposed harmonised EU rescue plan that can be proposed for the group as a whole (namely the relevant parent and subsidiaries). ${ }^{22}$

\footnotetext{
${ }^{18}$ Proposed article $2(\mathrm{a})$.

${ }^{19}$ Proposed article 44(4).

${ }^{20}$ Under articles 29-38 of the EC Insolvency Regulation. See proposed article 44.

${ }^{21}$ By analogy to article 33 of the Regulation. See proposed article 44(5).

22 Proposed article 45, and Chapter VI of the Report regarding the EU rescue plan. The plan may encompass some or all the entities.
} 
The analogy (to main-secondary proceedings) does not go all the way, though, to allow, for example, the group main liquidator to lodge claims of the parent's creditors in the subsidiary's proceedings, appreciating that the entities are separate and each has its own creditors. ${ }^{23}$ In addition, the information to be provided by the liquidator of the group main proceedings to liquidators of the subsidiaries is limited to information which is relevant to the subsidiary's insolvency proceedings. There is no obligation on the part of the liquidator of the group main proceedings to inform the subsidiary's liquidator of the progress made in lodging and verifying claims at parent level, except where the ultimate parent company and the subsidiary are liable for the same debt. ${ }^{24}$

Finally, it is suggested that in rare circumstances, where the assets, liabilities or agreements of one or more group companies cannot be attributed to a single company within a group and consequently the insolvency proceedings with respect to these companies cannot be conducted in a meaningful way, it will be possible to request the consolidation of the insolvency proceedings. ${ }^{25}$ If consolidation is allowed then all proceedings will merge into the main group proceedings, unless there is no parent company, in which case the surviving proceedings will be those to which the greatest value can be attributed. ${ }^{26}$ The request to consolidate proceedings should be addressed to the courts which may lose their supervisory role. ${ }^{27}$ Main proceedings opened in jurisdictions other than that of the surviving main proceedings, will be converted into secondary proceedings. ${ }^{28}$ The assets and debts are then

\footnotetext{
${ }^{23}$ See proposed article $44(1)$ and the commentary to article 44.

${ }^{24}$ Proposed article 44(3).

${ }^{25}$ Proposed article 46(1).

${ }^{26}$ Proposed article 46(2).

${ }^{27}$ Proposed article 46(3).

${ }^{28}$ Proposed article 46(4).
} 
pooled together, yet the court (of the surviving main proceedings) may take measures in order to compensate for any impairment of creditors which result from the consolidation. ${ }^{29}$

\section{Does the coordination regime address all group structures?- the limitations of the}

\section{definition of groups}

As noted above, INSOL's proposals refer to groups of companies comprised of parent and subsidiaries and suggest that proceedings will be coordinated by the main group liquidator at the parent company's COMI. The proposals thus refer to hierarchical pyramid group legal structures $^{30}$ of parent, subsidiaries and potentially sub-subsidiaries.

Indeed, enterprises comprising subsidiaries vertically held by parent companies represent the classic traditional and most common group structure. ${ }^{31}$ Yet, groups may take a multiplicity of forms including the more loosely connected networks of coordinated economic collaborations. ${ }^{32}$ In these structures the group may still achieve a degree of managerial control or otherwise may still coordinate the whole business. An example is a network of affiliates (with no principal holding company) linked by means of intra-group holdings operating in coordination by meetings of the managements and through interlocking directorships. ${ }^{33}$ Such structures are not addressed by the proposed definition.

Even within the hierarchical structures, the definition limits the scope of the proposal (and thus the coordination regime that can apply to group cases) to groups comprising of parent

\footnotetext{
${ }^{29}$ Proposed article 46(5).

${ }^{30}$ Below we will consider differences between groups in terms of their functional structure.

${ }^{31}$ See T Hadden "Regulating Corporate Groups: An International Perspective" in J McCahery S Picciotto and C Scott (eds) Corporate Control and Accountability (Oxford University Press, Oxford 1993) 343, 345-47.

${ }^{32}$ See Muchlinski, Multinational Enterprises and the Law (OUP, 2007), 33.

${ }^{33}$ The notable example is the Japanese keiretsu, or families of firms. See further T. Hadden, 'Regulating Corporate Groups: An International Perspective', in J. McCahery S. Picciotto and C. Scott (eds.), Corporate Control and Accountability (Oxford University Press, Oxford 1993) 343, 352-3.
} 
and subsidiaries, namely groups controlled by a legal person or a company. Therefore, affiliated ("sister") companies held together or controlled by an individual shareholder (or shareholders) are also excluded from the definition. Another hierarchical structure which is not covered as such in the definition is where the enterprise is split organizationally so that it is controlled via several sets of management (a twin-holding structure). ${ }^{34}$

In light of the dynamics of business forms and enterprise structures a broader definition of a corporate group should be preferred. A possible definition could be based on UNCITRAL recommendations in the new part of the UNCITRAL Legislative Guide on Insolvency Law. It refers to an enterprise group (rather than a corporate group, to reflect the fact that any type of entity could be included) and defines it as: "two or more enterprises that are interconnected by control or significant ownership". ${ }^{35}$ Thus, instead of defining only the key players in a group (a parent and a subsidiary), it defines the enterprise itself, which may take different forms, and may not necessarily take the traditional hierarchical structure of a holding company and subsidiaries. Entities may be linked by any means of control. An even more 'all inclusive' definition would be based on coordination as the connecting factor (the link) between the entities. ${ }^{36}$

Finally, in terms of the geographical location of the group entities (in particular the parent company which is supposed to serve as the coordinating proceeding), the definition fails to take account of situations where all possible parent companies of the group are located outside the EU. Since the definition (and the coordination regime) refers only to entities with COMIs in the EU, it may certainly be the case that the parent company controlling the

\footnotetext{
${ }^{34}$ See e.g. the Eurotunnel group, which operated under two parent companies (jointly held French and English Holding companies)- Eurotunnel SA and Eurotunnel plc, each of which owning respectively a French and English concessionary companies- France Manche SA and the Channel Tunnel Group Ltd.

${ }^{35}$ U.N. Comm'n on Int'I Trade Law [UNCITRAL] Legislative Guide on Insolvency Law 2004, Part III, para. 4(a).

${ }^{36}$ See further I Mevorach, Insolvency within Multinational Enterprise Groups (OUP, 2009), 22-25.
} 
subsidiary (or subsidiaries) has its COMI in a country outside the EU. In such a case there will be no relevant ultimate parent within the EU that can coordinate the proceedings.

\section{Does the coordination regime maximise insolvency goals, considering different}

\section{functional structures of groups?}

The idea that proceedings opened in different jurisdictions with regard to members of the same corporate group will be coordinated by a group main proceeding - opened in one of the countries involved in the process, will certainly promote efficiency. Efficiency in insolvency entails the maximisation of stakeholders' wealth by seeking the best solution for the enterprise in the course of insolvency and minimising costs involved in the process. ${ }^{37}$ If the corporate group was integrated in terms of how it operated its business then most likely the group as a whole (or some parts thereof) is worth more than the sum of the parts. Importantly, the group's stakeholders may benefit from a group-wide plan or a sale of the business (as a whole, or its viable parts which may cross subsidiaries) as a going concern. ${ }^{38}$ A coordinated approach can avoid separate sales of assets resulting from disintegration which may be value destroying as was apparent in the case of KPNQwest N.V.. ${ }^{39}$ It can also avoid lack of smooth cooperation between affiliates. A notable example (not of an EC Regulation case) is the Lehman Brothers case where the UK administrators of Lehman Brothers International

\footnotetext{
${ }^{37}$ See e.g. O Williamson and S Masten The Economics of Transaction Costs (Edward Elgar Publishing, Aldershot 1999)). See also Mokal, Corporate Insolvency (n 74 chapter 2), 20-27. See also I Mevorach, Insolvency within Multinational Enterprise Groups (OUP, 2009), Ch 4 on the manifestation of shared insolvency goals in the UNCITRAL Legislative Guide on Insolvency Law.

38 I Mevorach, Insolvency within Multinational Enterprise Groups (OUP, 2009), Ch 6.

${ }^{39}$ KPNQwest group owned cables in Europe and across the Atlantic Ocean. The cables ran through various countries and were owned by subsidiaries of the group situated in these countries. On 31 May 2002 the Dutch parent company entered bankruptcy proceedings. As a result, many of its subsidiaries were put under insolvency process as well (see Van Galen, Robert, "The European Insolvency Regulation and Groups of Companies", INSOL Europe Annual Congress, Cork, Ireland, 16-18 October 2003.
} 
(Europe) (LBIE) refused to become a party to a cross-border protocol proposed by the US Bankruptcy court. $^{40}$

In this respect, it is particularly significant that INSOL avoided the more territorialist and entity-based solution, ${ }^{41}$ whereby the coordination between the proceedings of group members would take place on a completely equal basis, and thus none would have a supervisory or coordinating role. Such a solution would still be better than conducting completely separate proceedings with no link between them, ${ }^{42}$ but will still entail the problem of lack of central direction. In such case, each entity may pull in its own direction and act in a self-serving manner even under a cooperative regime. Achieving group wide solutions, especially reorganisation, may be much more difficult. ${ }^{43}$

INSOL also avoided, though, suggesting a stronger universalist and enterprise-based solution that would direct all relevant group member proceedings (at least in certain cases) to the same jurisdiction and promote centralisation of the process. It is explained in the commentary to the proposal that INSOL's aim was to avoid a "one-size-fits-all” solution whereby in all cases of groups full centralisation will be applied. Importantly, INSOL noted the problem of defeating creditors' expectations and the possible redistribution of their rights if COMI is shifted to the forum of the group centre. It is explained that "contrary to the present situation the mere location of the subsidiary's registered office would no longer suffice to establish

\footnotetext{
${ }^{40}$ See SD Sano, "The third road to deal with the insolvency of multinational enterprise groups" (2011) J.I.B.L.R. 15. Additional problems arose regarding disclosure of information.

${ }^{41}$ The territorialist approach to cross-border insolvency advocates a state-by-state proceeding, possibly with a certain degree of cooperation. The opposing school of thought is universalism which suggests that crossborder insolvency should be as much as possible unified and centralised in a single forum (see L Westbrook, "Multinational Enterprises in General Default: Chapter 15, The ALI Principles, and The EU Insolvency Regulation" (2002) 76 Am. Bankr. L.J. 1). Entity law stresses the separateness between the group members. The opposing 'enterprise doctrine' suggests to consider the group as a whole for various legal purposes (see AA Berle Jr "The theory of enterprise entity" (1947) 47 Colum L Rev 343, 352).

42 See I Mevorach, "Towards a Consensus on the Treatment of Multinational Enterprise Groups in Insolvency" 18 Cardozo J. Int'I \& Comp. L. 359 (2010), 359, 419-420.

${ }^{43}$ I Mevorach, Insolvency within Multinational Enterprise Groups (OUP, 2009), 153-159.
} 
with a fair degree of certainty the location of the centre of main interests, and hence the insolvency regime applicable to main proceedings. $" 44$

Indeed, for some types of group (in terms of their functional structure) centralisation of the process in a single jurisdiction may not be adequate. This would be the case in decentralised groups where subsidiaries had significant autonomy, were separately managed and clearly had their own COMI in their local market. ${ }^{45}$ Groups of this sort may take different legal forms. Certainly, a classic pyramid group structure may operate either as a centrally controlled enterprise or a more decentralised one. Furthermore, parts of a group may be closely controlled while certain subsidiaries operate independently. In any event, with regard to the decentralised parts, shifting the COMIs of the subsidiaries to some other jurisdiction may defeat creditors' expectations and redistribute rights. It is widely acknowledged that respecting pre-insolvency acquired right is paramount to efficiency in insolvency, allowing creditors to calculate their risk and avoiding premature liquidations. ${ }^{46}$

It is also noted in the commentary to the proposals that even if centralisation of the proceedings in a single jurisdiction was a viable and desirable solution, it is most likely that additional secondary proceedings would be opened. Apparently, this is because "usually the subsidiary will still have an establishment in its country of incorporation..."47. In light of these considerations (the drawbacks of shifting the subsidiary's centre), the proposals preferred a "less drastic solution" 48 whereby multiple proceedings will be opened in different jurisdictions and would only be coordinated centrally.

\footnotetext{
${ }^{44}$ Commentary to Chapter V of the proposal, para. V.3.

${ }^{45}$ See I Mevorach, Insolvency within Multinational Enterprise Groups (OUP, 2009), 134.

${ }^{46}$ See e.g. T Jackson The Logic and Limits of Bankruptcy Law (Harvard University Press, Cambridge MA 1986); DG Baird and T Jackson "Corporate Reorganization and the treatment of Diverse Ownership Interests: A Comment on Adequate Protection of Secured Creditors" (1984) 51 Univ. of Chicago Law Rev. 97.

${ }^{47}$ Commentary to Chapter V of the proposal, para. V.3.

${ }^{48}$ Commentary to Chapter V of the proposal, para. V.4.
} 
The problem with this solution (a coordinated regime of a multijurisdictional process) is that we are back with a "one-size-fits-all" approach where we will always seek to decentralise the process and have a multijurisdictional proceedings. At least this is the solution envisaged in the proposal. Admittedly, it is possible under the proposal to open all the proceedings in a single jurisdiction. There is nothing precluding this course of action. However, this solution is not the one explicitly suggested. Therefore, parties (as well as courts) following the guidelines in the proposals would probably expect to find the COMI of the subsidiaries at a place separate from that of the parent's (most likely the registered office or location of assets or creditors). In view of the variety of group functional structures, in particular the fact that while some groups may be decentralised many others may be centralised (closely managed as a whole from a single head office), the solution must be somewhat more nuanced in order to maximise the promotion of insolvency goals.

The proposed clarification to the notion of COMI (in Chapter I of the report) might further diminish the possibility of achieving efficient group centralisations. On the one hand, the proposed new definition (delineated above) stresses the importance of the operational headquarters in determining the location of the COMI. This factor is elevated above other possible connecting factors, such as location of operations, activities, assets, creditors or employees. This approach is highly commendable and could be conducive to group centralisations, since the operational head office is usually the meeting point of all group members in cases of a centralised group. ${ }^{49}$ However, INSOL continues and suggests that the mere fact that the economic choices and decisions of a company are or can be controlled by a parent company in another Member State than the Member State of the registered office does

\footnotetext{
${ }^{49}$ See 'The Home Country of a Multinational Corporate Group Facing Insolvency' (2008) 57 ICLQ 427.
} 
not cause the centre of main interests to be located in this other Member State ${ }^{50}$ which brings us back to square one.

This addition to the definition is taken from the ECJ decision in Eurofood ${ }^{51}$ which in 2006 provided the first ECJ judgement regarding COMI. It was determined in this case that Parmalat group's subsidiary Eurofood's COMI was in Ireland (when it has its registered office) rather than Italy (the group headquarters). In this case, proceedings were first opened in Ireland and so Italy had to automatically recognise the Irish decision (as required under the Regulation $^{52}$ ). Yet, the ECJ further explained that with regard to subsidiaries, the fact that they are controlled by a parent registered elsewhere may not, of itself and without more, shift their COMI. Other objective factors are required in order to rebut the registered office presumption. In particular, the presumption may be rebutted in the case of a company not carrying out any business in the territory of the member state in which its registered office is situated. ${ }^{53}$ This seems to have done little to clarify COMI as the ECJ did not explain which factors could in fact rebut the presumption, and what the important connecting factor between a company (including a subsidiary) and the jurisdiction is.

It can be contrasted, in this respect, with the more recent decision of the ECJ in Interedil ${ }^{54}$ where a much clearer explanation of the meaning of COMI was provided:

“... a debtor company's main centre of interests must be determined by attaching greater importance to the place of the company's central administration, as may be established by objective factors which are ascertainable by third parties. Where the bodies responsible for the management and supervision of a company are in the same place as its registered office and the management decisions of the company are taken, in a manner that is ascertainable by third parties, in that place, the presumption in that provision cannot be rebutted. Where a company's central administration is not in the same place as its registered office, the presence of company assets and the existence of contracts for the financial exploitation of those assets in a Member State other than

\footnotetext{
${ }^{50}$ Note 19 and accompanying text.

${ }^{51}$ Eurofood IFSC Ltd (Case C-341/04) [2006] OJ 2006 C143/11.

${ }^{52}$ See article 16 of the Regulation.

${ }^{53}$ Eurofood IFSC Ltd (Case C-341/04) [2006] OJ 2006 C143/11 at [36-37].

${ }^{54}$ Interedil Srl (Case C-396/09) [2011] ECR.
} 
that in which the registered office is situated cannot be regarded as sufficient factors to rebut the presumption unless a comprehensive assessment of all the relevant factors makes it possible to establish, in a manner that is ascertainable by third parties, that the company's actual centre of management and supervision and of the management of its interests is located in that other Member State"

In a case of a centrally managed group (which in functional terms may operate as a single company with branches) the management decisions are typically taken centrally at the head office which will be a mutual COMI of the respective subsidiaries. The coordination regime suggested in INSOL's proposal, which is based on decentralisation in insolvency may, therefore, result in a mismatch between the economic reality (namely the actual functional structure of the group) and the legal solution.

Finally, the proposal is at odds with the practice. Thus, the experience of applying the Regulation shows that (even in the absence of rules for groups) in many if not most cases of groups, full centralisation regarding some or all relevant entities of the group was possible. Examples are numerous and include cases such as Daisytek, ${ }^{56}$ Crisscross,${ }^{57}$ Cirio Finance Luxemburg SA, ${ }^{58}$ Collins and Aikman, ${ }^{59} \mathrm{MG}$ Rover,${ }^{60}$ Hettlage KghA, ${ }^{61}$ Parmalat Capital Netherlands BV, ${ }^{62}$ Aim,${ }^{63}$ Nortel, ${ }^{64}$ MPOTEC/ EMTEC, ${ }^{65}$ Energotech, ${ }^{66}$ Zenith group, ${ }^{67}$

\footnotetext{
55 Interedil Srl (Case C-396/09) [2011] ECR at [59].

${ }^{56}$ Daisytek- ISA Ltd High Court of Justice Leeds (UK) 16 May 2003, [2003] BCC 562 (Ch D).

${ }^{57}$ Crisscross Telecommunications Group, Re High Court London, Chancery Division (UK) 20 May 2003 (unreported).

${ }^{58}$ Cirio del Monte Court of Rome (Italy) August 2003 (unreported).

${ }^{59}$ Collins \& Aikman Europe SA High Court of Justice (Chancery Division Companies Court) (UK) 15 July 2005, [2005] EWHC 1754 (Ch D).

${ }^{60}$ MG Rover Germany Court of Düsseldorf (Germany) 14 July 2005 (Az. 502 IN 110/05) (unreported).

${ }^{61}$ In Re Hettlage KghA District Court of Munich (Germany) 4 May 2004, ZIP 2004, 962 (AG Munchen Beschl v4.5.2004-1501 IE 1276/04).

62 PARMALAT Capital Netherlands BV Court of Parma (Italy) 4 February 2004.

${ }^{63}$ Aim Underwriting Agencies (Ireland) Ltd, Re High Court London Chancery Division (Company Court) (UK) 2 July 2004, [2004] EWHC 2114 (Ch).

${ }^{64}$ Nortel Networks High Court of Justice Chancery Division Companies Court (UK) 14 January 2009.

${ }^{65}$ Emtec Commercial Court of Nanterre (France) 15 February 2006, BCC 681

${ }^{66}$ Energotech SARL Tribunal de Grande Instance Lure (France) 29 March 2006, [2007] BCC 123.

${ }^{67}$ Zenith Machinenfabrik Austria GesmbH Court Klagenfurt (Austria) 2 July 2004, NZI
} 
Lennox Holdings, ${ }^{68}$ and Kaupthing Capital Partners. ${ }^{69}$ In these cases, the proceedings regarding some or all the subsidiaries were conducted from a single jurisdiction - that of the head office of the group, which could be regarded as the COMI of each of the subsidiaries, due to the centralised nature of the group. It may not be a mere coincidence that in many group cases a mutual COMI could be identified (i.e. that they were centrally controlled integrated groups). Indeed, in this kind of functional structures, the likelihood of a group collapse is greater.

It is worth noting that in some of those centralised cases it was also possible to avoid the opening of additional secondary proceedings, by sending letters of request, giving assurances to local creditors or applying the law of the (potential) secondary forum. ${ }^{70}$ In other words, the trend has been thus far one of pragmatism and efficiency, seeking centralisations in insolvency and avoiding the opening of multiple proceedings in different jurisdictions in cases of groups. Indeed, by avoiding the opening of such multiple proceedings considerable costs can be avoided. Clearly, with a concentrated process cooperation is smoother, information is more readily available, court hearings can be easily conjoined and so forth. In other words, wealth is maximised, which is one of the key goals of insolvency. ${ }^{71}$ There is no redistribution of rights or defeat of legitimate expectations either, as the centralisation follows the functional reality whereby the entities were centrally controlled. The group centre thus matches the entities' centre, which should be generally apparent to voluntary creditors. In borderline cases, it is possible to compensate specific creditors or apply local laws using the same mechanisms imposed in cases where opening of secondary proceedings was avoided.

\footnotetext{
2004, 677.

${ }^{68}$ Lennox Holdings plc Chancery Division (UK) 20 June 2008, [2009] BCC 155.

${ }^{69}$ Kaupthing Capital Partners II Master LP Inc, Re [2010] EWHC 836, [2011] BCC 338.

${ }^{70}$ See MG Rover Germany Court of Düsseldorf (Germany) 14 July 2005 (Az. 502 IN 110/05) (unreported); Collins \& Aikman Europe SA High Court of Justice (Chancery Division Companies Court) (UK) 15 July 2005, [2005] EWHC 1754 (Ch D); Nortel Networks High Court of Justice Chancery Division Companies Court (UK) 14 January 2009.

${ }^{71}$ Note 38 and accompanying text.
} 
The aim and possible mechanisms of avoiding the opening of additional proceedings (be it main or secondary), regarding subsidiaries in the jurisdictions where they had economic presence (i.e. activities, assets, employees and so forth) is omitted from INSOL's recommendation. There is no clear provision (or even commentary) stating that since COMI refers mainly to the objective head office of the company (as INSOL suggests) in cases of centralised groups this would usually be the same COMI for all group members. Nor is there an explanation or suggestion that in such cases it is further possible to avoid the opening of secondary proceedings where it appears that this may not be practical and would incur unnecessary further costs. This is peculiar in light of the approach adopted in the proposals regarding the opening of secondary proceedings. In the proposed amendments to article 27 of the EC Regulation (which allows the opening of secondary proceedings) INSOL suggests that courts would have discretion to abstain from opening secondary proceedings. It is not clear to what extent this approach could apply to opening main proceedings regarding subsidiaries and if so in what ways. The avoidance of centralisation is also at odds with the approach to substantive consolidation (which will be discussed below) where there is greater appreciation of the differences between groups' functional structure. There, it is allowed for certain types of groups to apply a stronger (enterprise based) solution under which assets and debts will be mixed together in the course of insolvency, and to 'correct' any 'errors' in specific cases by compensating the relevant creditors.

Again, a better approach would be somewhat more nuanced. It would explicitly provide for three options. Where the group was integrated and centralised and it is possible to identify a mutual COMI for the group members (in the operational head office) then multiple proceedings should be avoided. A similar approach is proposed by the European Parliament in a draft report with recommendation to the Commission on insolvency proceedings in the 
context of EU company law. ${ }^{72}$ There, a flexible regime for the regulation of the insolvency of groups is suggested. Specifically, it is proposed that whenever the functional/ownership structure allows it, proceedings should be opened in the Member State where the operational headquarters of the group are located which should then be recognised automatically. ${ }^{73}$ Yet, in other cases where subsidiaries were separately managed, a coordination regime of the sort envisaged by INSOL would be most adequate. A third scenario is where it is not possible to locate a mutual coordination centre, e.g. at the ultimate parent's $\mathrm{COMI},{ }^{74}$ in which case coordination may proceed on a more equal basis by applying mandatory rules for cooperation and coordination. The latter type of solution is also absent from the INSOL's proposals.

\section{Maximising fairness and efficiency in cases of intermingled groups}

Not many jurisdictions allow for substantive consolidation in their legislation. The concept is undoubtedly contentious since it entails the mixing of assets and debts of otherwise separate legal entities, ignoring the 'corporate veil'. ${ }^{75}$ It means that rights may be redistributed in the course of insolvency as 'unless the asset to liability ratio is equal, substantive consolidation will necessarily reduce the bankruptcy distribution to some group of creditors or equity owners. $^{76}$

In those regimes that do adopt the doctrine, there is often uncertainty as to the precise circumstances where substantive consolidation should be allowed. Under the New Zealand

\footnotetext{
${ }^{72} 2011 / 2006$ (INI), 6.6.2011.

73 lbid, part 3, para. 1.

${ }^{74}$ As noted above, the parent may be outside the EU, or there may be more than one parent or no parent at all.

${ }^{75}$ See I Mevorach, 'European Insolvency Law in a Global Context' (2011) 7 J.B.L. 666, 671-672.

${ }^{76}$ C.W. Frost, 'Organizational Form, Misappropriation Risk, and the Substantive Consolidation of Corporate Groups' (1993) 44 Hastings L.J. 449, 451. See also D.G. Baird, 'Substantive Consolidation Today' (2006) 47 Bost. Col. L. Rev. 5, 6 (claiming that under substantive consolidation scheme 'some general creditors fare better and others worse').
} 
pooling regime, one of the factors to be considered in deciding whether to make a pooling order is 'the conduct of any of the companies towards the creditors of any of the other companies'. ${ }^{77}$ This was interpreted as essentially meaning the degree of confusion of the creditors of the companies as to which company they had been dealing with, ${ }^{78}$ although mere reliance by creditors of a company on the fact that another company is, or was, related to that company is apparently not a ground for making such an order. ${ }^{79}$ Under the US bankruptcy regime, substantive consolidation may be allowed in cases where creditors of affiliate companies have dealt with these entities as a single economic unit, and have not relied on their separate identities when extending credit. ${ }^{80}$ Substantive consolidation is regarded as an equitable tool and may also be used as a remedy against improper and misleading corporate behaviour. ${ }^{81}$ Irish law allows, in legislation, ordering the pooling of the assets and debts of related companies together whenever this is "just and equitable" (while taking into account a range of factors). ${ }^{82}$

As noted above, INSOL suggests allowing the merging of proceedings only in circumstances where the affairs of companies belonging to the same group were intermingled. This proposal is very appropriate. It is in this kind of group functional structure (and in this kind only) ${ }^{83}$ that substantive consolidation will not result with redistribution and would not be unfair. It would also be the least costly course of action, and would not defeat the merits of limited liability

\footnotetext{
77 Section 272(2)(b) of New Zealand Companies Act 1993.

${ }^{78}$ See In Re Dalhoff \& King Ltd (1991) 5 NZCLC 66, 959.

${ }^{79}$ New Zealand companies Act 1993, s 272(3).

${ }^{80}$ See e.g. Soviero v Franklin National Bank 328 F. 2d. 446 (2 $2^{\text {nd }}$ Circ 1964); Union Sav. Bank v. Augie/Restivo Baking Company (In re Augie/Restivo Baking Co) 860 F 2d 515 (2d Cir 1988); In re Owens Corning, 419 F.3d (3d Cir 2005)).

${ }^{81}$ See Chemical Bank N.Y. Trust Co. v. Kheel 369 F.2d 845, 847 (2d Cir 1966)); Union Sav. Bank v. Augie/Restivo Baking Company (In re Augie/Restivo Baking Co) 860 F 2d 515 (2d Cir 1988).

${ }^{82}$ E.g. the conduct of the related company towards the company being wound up. See Irish Companies Act 1990 s.141.

${ }^{83}$ I have termed these types of group 'asset integrated groups', namely groups integrated in terms of their assets or debts. Here there was a significant degree of 'entity unity', in the sense that the financial affairs of the enterprise's entities were entangled (see I Mevorach, Insolvency within Multinational Enterprise Groups (OUP, 2009), 132).
} 
and 'asset partitioning' ${ }^{84}$ In those groups that were heavily integrated (in terms of their assets and debts) there was 'a façade of asset partitioning' ${ }^{85}$ That is, the evidence suggests that there was no partitioning as a matter of economic realities. Furthermore, the intermingling between the entities in these scenarios resulted in a situation where all creditors in fact belonged to the group as a whole, and therefore a fair distribution means that all assets of the group should be available for distribution to all creditors. The claims subject to the substantive consolidation order cannot be ascertainable against a specific group member (with reasonable effort) and therefore it cannot be shown that a creditor could have gained more by remaining 'attached' to a particular entity. A substantive consolidation mechanism allows for a group-wide distribution (and avoids an arbitrary distribution of assets on a member-by-member basis), and also eliminates costs of attempting to untangle the web of connections. The possibility to exclude certain entities or certain creditors from the substantive consolidation in case their debts were ascertainable ${ }^{86}$ further ensures that there is no 'redistribution' of rights. ${ }^{87}$

The only limitation with INSOL proposals in this respect is where they stress that only in circumstances where it is impossible to disentangle the businesses of the relevant group members, substantive consolidation should be allowed. Specifically, it is mentioned that substantive consolidation should not be allowed when it is only costly to separate the business. It must be appreciated, though, that this distinction (between impossible and costly) is a very fine one, and one can litigate extensively on whether disentangling is very costly,

\footnotetext{
${ }^{84}$ The segregation of assets and debts between a company and its shareholders or the members of a corporate group reduces transaction costs as creditors do not need to monitor the creditworthiness of other group members when they extend credit to a particular entity. (H Hansmann and R Kraakman "The Essential Role of Organizational Law" (2000) 110 Yale L.J. 387).

${ }^{85}$ This matter is further discussed in Mevorach (n 9), chap 6 section 6.3.

${ }^{86}$ See note 30 and accompanying text.

${ }^{87}$ For a different approach see D Staehelin, "No substantive consolidation in the insolvency of groups of companies" in H. Peter, N. Jeandin and J. Kilborn (eds.) The Challenges of Insolvency Law Reform in the 21st Century (Schulthess Zurich, 2006) 213, 217.
} 
extremely costly or completely impossible. In this respect it seems that the drafting of the recommendation (regarding substantive consolidation) proposed by UNCITRAL is preferable as it refers to circumstances where the assets or liabilities of the enterprise group members are intermingled to such an extent that the ownership of assets and responsibility for liabilities cannot be identified without disproportionate expense or delay. ${ }^{88}$

It is notable that this solution is gradually gaining support on the international level. UNCITRAL has included substantive consolidation in the new addition to the Insolvency Guide. ${ }^{89}$ The European Parliament has also suggested (in the draft report to the Commission mentioned above), that in circumstances where the assets of the group are so confused that the estates cannot be kept separate, substantive aggregation should apply. ${ }^{90}$

\section{Concluding remarks}

No doubt the proposals of INSOL could contribute to reform considerations within Europe as well as in other regions or internationally. It can also be a source for ideas for national regimes considering reform in this area. Specifically, the concept of substantive consolidation suggested by INSOL is very appropriate as it is confined to a limited scenario where the group's affairs were highly intermingled. It is also generally in line with other proposals on the international level. It can be predicted that in light of the growing consensus on the contours of substantive consolidation, the concept can be taken on board by the Commission when revising the EC Regulation. However, it is also possible that substantive consolidation will be viewed as a concept that does not fall squarely within the ambit of the EC Regulation

\footnotetext{
${ }^{88}$ U.N. Comm'n on Int'l Trade Law [UNCITRAL] Legislative Guide on Insolvency Law 2004, Part III, recommendation 220(a).

${ }^{89}$ See further, I Mevorach, "Is the future bright for enterprise groups in insolvency? -analysis of the new recommendations of UNCITRAL on the domestic aspects" in P. J. Omar, (ed.) International Insolvency Law: Reforms and Challenges (Ashgate, forthcoming), available in Nottinhgam University's ePrints.

${ }^{90}$ 2011/2006(INI), 6.6.2011, part 3, para.1(E).
} 
(which is primarily a private international law tool). If this will be the case, then substantive consolidation (and possibly other provisions for groups including the avoidance of transactions involving group members and group reorganisations ${ }^{91}$ ) may be adopted in a different regulation or a directive.

The coordination regime proposed by INSOL is essential, especially in cases of an integrated group whose stakeholders could benefit from group-wide solutions. The idea of letting a 'group main proceedings' to coordinate the process will further facilitate such solutions (though situations where an EU ultimate parent cannot be identified should also be taken into account). However, in many cases groups are centrally controlled in the course of business. Therefore, it should be stressed that in these cases a more efficient solution could be achieved if a multijurisdictional process is avoided and the proceedings are centralised in a single forum. It is very likely that the notion of coordination of group insolvency proceedings will be embraced within the forthcoming revised version of the Regulation. Generally, there is room for improvement of the provisions regarding cooperation between main and secondary proceedings (in single company cases) in the Regulation. Thus, while expanding the relevant provisions (e.g. delineating methods of cooperation such as the use of protocols and court-tocourt communication) it is sensible to ensure that they can apply to groups as well, explicitly allowing cooperation between parallel proceedings involving members of the same corporate group. ${ }^{92}$ As such, it is hoped that the revision will take that additional step and adopt INSOL's idea of allowing coordination by one of the forums. Indeed, even full centralisation (avoiding multiple proceedings) in the relevant cases seems an achievable outcome in the

\footnotetext{
${ }^{91}$ Considering INSOL's proposals in Chapter $\mathrm{VI}$ of their Report (on group rescue plans), and possibly also UNCITRAL's recommendations on the domestic aspects pertaining to enterprise groups in insolvency (in Part III of the UNCITRAL Legislative Guide). Specifically, recommendations 217-218 deal with voidable transactions involving enterprise groups and recommendations 237-238 with group reorganisations.

92 See also UNCITRAL's recommendations regarding cooperation between parallel proceedings against group members (recommendations 240-254, Part III of the UNCITRAL Legislative Guide) which also include the possibility of appointing the same insolvency representative to all group members' proceedings; I Mevorach, 'European Insolvency Law in a Global Context' (2011) 7 J.B.L. 666, 673-675.
} 
current round of amendments. ${ }^{93}$ This is also a solution which has been advocated by the European Parliament (centralisation in the operational headquarters, where the functional structure allows it). ${ }^{94}$ It, therefore, might not be too far-fetched.

\footnotetext{
${ }^{93}$ See also I Mevorach, 'European Insolvency Law in a Global Context' (2011) 7 J.B.L. 666, 675-679.

${ }^{94}$ See note 73.
} 